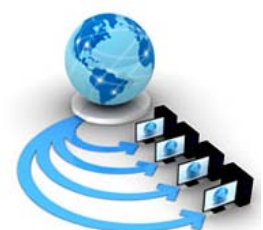

Volume 10, No. 3, May-June 2019

ISSN No. 0976-5697

International Journal of Advanced Research in Computer Science

RESEARCH PAPER

Available Online at www.ijarcs.info

\title{
ENHANCING MENTORING BETWEEN ALUMNI AND STUDENTS AT MIDDLE EAST COLLEGE: AN ANDROID MOBILE APPLICATION USING DATA MINING TECHNIQUES
}

\author{
Najat Khalifa \\ Dept. of Computing Middle East College \\ Muscat, Sultanate of Oman
}

\author{
Puttaswamy M R \\ Dept. of Computing Middle East College \\ Muscat, Sultanate of Oman
}

\author{
Raza Hassan \\ Dept. of Computing Middle East College \\ Muscat, Sultanate of Oman
}

\begin{abstract}
Graduates are a very important part of universities and colleges where graduates' participation can be considered common among universities and colleges these days. The idea of implementing a mobile application for alumni association is to associate all the alumni together with Middle East College and make the association more active and interactive through a high involvement. We are aware of the importance of graduate students where they can be considered as the key function for any university and any college. Furthermore, it is very important to utilize the power of the graduates. In this paper we propose a framework on how to building a mobile application for alumni association can enhance mentoring between alumni and students of Middle East College using data mining. It is not easy to apply data mining to enhance mentoring between alumni and current students. In the mobile application simple data mining algorithms are performed for more interactive between the alumni and current students.
\end{abstract}

Keywords: Data mining, KDD, Classification, Mobile application.

\section{INTRODUCTION}

This research paper provides a study on developing a smart alumni android mobile application for enhancing and mentoring between alumni and students at Middle East College using data mining. The app is designed to create a supported and an engaged alumni network which allow alumni to be in contact with their college and provide mentoring the current students of Middle East College (MEC). At present, there is no mobile application provided for alumni of Middle East College (MEC), only a simple page provided in college SIS which allows alumni to register in alumni association and update their details. So, there is a limitation on the system users, where only alumni can use it, also a limitation on the system functionality, and if alumni want to do any other task, he/she should come to college. The current system only constitutes a registration system for the graduate to become a member of the College Alumni Association. There is no any interaction between the graduates themselves through the system, all the interactions happen in the college campus. The other thing is that the current students cannot attend the alumni gatherings because current students are not allowed to attend the alumni activities. So, the graduates who attend the gatherings can share and exchange their knowledge between each other, and successful alumni can provide a mentoring to those who are still looking for a job or opportunities. The graduates who do mentoring they can only do this in the college campus there is no system can be used to do mentoring between alumni or the current students. Using a mobile app to do mentoring between alumni and student can be more effective and easier than doing that manually. The chance of increasing the involvement of college alumni to the college alumni association will be big, as the mobile application can be considered as a more user-friendlysystem where users can effectively interact with it. Because in fact it is not just a process of registering and modifying user information. Educational institutions are playing an important role in the society, it needs to enter the technology to it in order to facilitate learning, improving performance of the institutions processes and enhancing the institutions environment. Proving a mobile application for alumni association can decrease the workload of the association staff. Many literature studies were conducted on the related topic to the recent problem.

\section{SCOPE}

A mobile application is required by Middle East College to enhance the alumni association process and increase the alumni involvement to the Middle East College alumni association. This app will activate alumni association of Middle East College and enhance mentoring between alumni and current students. The app will be used by alumni, current students, and faculty and association staff. The app will improve the association processes and will decrease the workload. Moreover, the association staff will perform an effective monitoring on the alumni system in easy way. 


\section{NEED FOR BETTER ALUMNI SYSTEMS}

\section{Existing system}

Middle East College is only having a simple part in the college SIS for alumni to allow them to be registered into alumni association. The system stakeholders are limited as it is only built for the college alumni. Alumni students who are willing to be in contact with college or who are willing to domentoring has to go the college and do that there. Such college needs an interactive alumni network as it is very keen on its students, building one platform that focusing on gathering alumni, current students and college staff into one platform so they can utilize the alumni association services.

\section{Proposed system}

The mobile application allows current student who looks for Middle East College alumni who providing mentoring for the current students through a very fast search on the app database according to their criteria. Moreover, alumni can post their stories and share it to the app's users through the alumni story page. All users can obtain other user's information through the app. Middle East College staff can easily obtain their previous students through the application. Admin can easily verify the users registered into the app, users are able to fill their details in user profile page and update their details whenever they want to do any updates. Nowadays, we need to develop an attractive mobile application which involves as much as possible of users. As graduates are a very important part of the college it is very important and necessary to attract current students to use the program because tomorrow, they will become graduates and are fully aware of the importance of this application.

Table 1: Attributes description of MEC alumni mobile application.

\begin{tabular}{|l|l|}
\hline Stakeholder & Description \\
\hline Alumnin & $\begin{array}{l}\text { Person who have rights } \\
\text { to maintain the system \& giving access } \\
\text { to users. } \\
\text { Mentor }\end{array}$ \\
\hline $\begin{array}{l}\text { Gradated student from MEC. } \\
\text { Gradated student from MEC, he is } \\
\text { interested in mentoring others and share } \\
\text { his/her knowledge. }\end{array}$ \\
\hline Current student & $\begin{array}{l}\text { Student who looks for mentoring from } \\
\text { alumnus. }\end{array}$ \\
\hline Faculty & $\begin{array}{l}\text { Faculty Members } \\
\text { Who are working on different } \\
\text { departments in MEC college. } \\
\text { Who posts MEC alumni association } \\
\text { events. }\end{array}$ \\
\hline
\end{tabular}

\section{DATA MINING TECHNIQUES}

Data mining is all about knowledge discovery by using several algorithms used to perform search operations that reveal the interconnection of data. However, the knowledge is a useful pattern can be extracted from huge amount of data so useful data will be detected. Moreover, with data mining users can get high response of data as data mining can analyze data in less time. Smart decision can be performed by manager if they are using data mining for data analysis it would help them in solving problems faster. Data mining is a strong AI tool, which can extract useful information through some analysis. Thus, the extracted information can help in doing decision making successfully. Many algorithms can be applied and get a helpful result for examples doing some regression technique can perform a very good financial analysis. The useful information can be called knowledge which can be discovered form huge amount of data as the user's needs. Data mining can answer many business questions. There are three steps to be taken to achieve data mining approaches which are: Exploration,pattern identification and deployment. With data mining it would be easy to forecast the trends and behaviors. Furthermore, we can apply data mining in new or an existing system, and within aminuet it can analyses big database. Sometimes there are some hidden patterns where can be as the result or the solution of the business problems, with the use of data mining it would be easy to detect this type of patterns. Different models we can find them in data mining which can be used to understand the difficult data and it leads to enhance the prediction.

\section{Classification}

It is the mostly used technique which includes a set of previously categorized samples to create a model that can classify the large group of data. This technique helps to generate important information about data and metadata. Classification is closer to clustering technique and it can be done within two functions learning and classification.

\section{Association rule technique}

The association between the items can be find using this technique. There is a relationship between two or more items which can be detected using the Association rule technique. This technique provides support and confidence.

\section{Visualization}

This technique is very useful in discovering patterns. Many researchers using this technique to produce the projection.

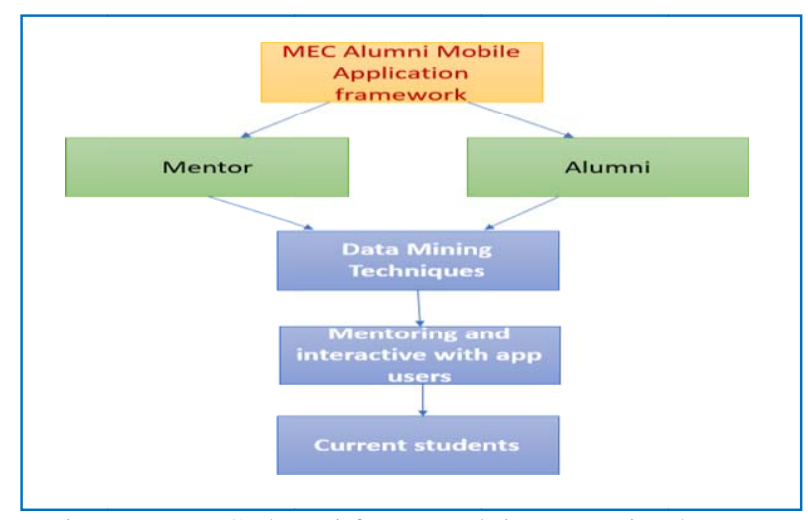

Figure 1: MEC alumni framework in mentoring between alumni, mentors and current students

MEC alumni app users can interact with the mentors who agreed to communicate with other user and share knowledge and opinion. As the alumnus are registered as a mentor to help MEC users who are using the app in the field of job and trainings and anything helps the users on their future status. So each user while doing the registration should specify the purpose of being in MEC alumni mobile application. For example, the faculty will register into the app to know the status of their old students and be in touch with alumni association of Middle East College. Moreover, current students will have a background about the job requirements that are related to their specialization and what 
re the available jobs that are very appropriate to their specialization. Also, current students will have a good chance to communicate with old alumnus who are interested to mentor the current students and their colleagues. For Alumni, it will be a very good chance to him to see the college new news and the status of Middle East College, and, he/she can see his/her college friends and teachers.

Moreover, whenever s/he thinks that s/he is so interested to do mentoring to any current student, or any alumni needsmentor on any educational aspect.

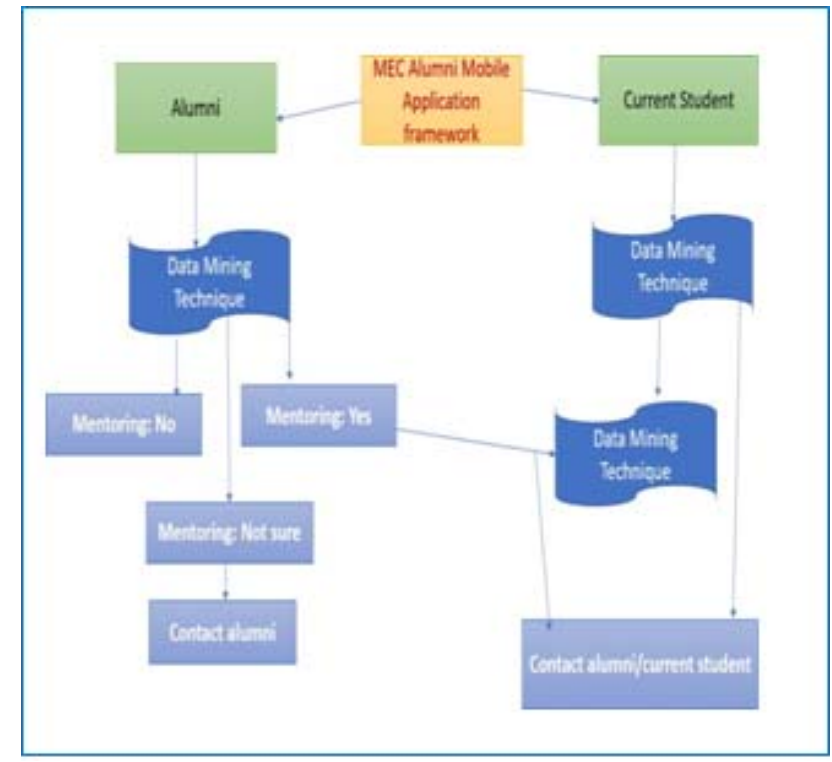

Figure2: Mentoring process

\section{APPLICATION PAGES}

\section{Login Page}

Each user should provide his/her email and password to use the application. Different users can login to the application such as current student, alumni, faculty, event manager, and the admin. Each user is having his specific tasks to do within the application. Alumni can post his own story if he thinks that it is attractive. Event manager can manage event page by adding deleting editing the event posts into the app. Faculty can view the app pages and manage his profile.

\section{Registration page}

To feel free to use the application each user must register first then the app will allow them to login into the app. Various gabs should be filled by the user to complete his registration such as user name, data of birth, specialization, user photo, email, password act. For more security and privacy each user must provide his college id picture to make sure that the user is from Middle East College.

\section{Alumni story:}

Each story actually posted by the alumnus themselves. The idea of this page is to motivate the users and be affected by the stories.

\section{Alumni list}

This page views all alumnus registered into the application. Each user finds their college mates within this list. By the user name each user can search for any alumni who is looking for.

\section{Gallery}

User will feel free to browse the photo gallery of the Alumni Association of the College. The event manager posts theassociation events in this page also. Users can be in touch with college current events.

\section{Jobs Page}

This page reviews the jobs and training opportunities are available now. Alumni can look on what chances are available to him to apply. The event manager posts whatever new jobs advertisements.

\section{Mentors list}

This page views all the mentors who are interested to do mentoring for alumnus or current students. Current students and any alumni can easily view this page and see all the mentors name attached with their profile's links. Users can search for mentors according to their specialization and they have the ability to add their favorite mentors into their mentors list. Each mentor is having rate, so the mentees can rate any mentors after the mentoring finished.

\section{LITERATURE REVIEW}

Sultan Qaboos University it is recognized as the best educational institution in Oman. It has an alumni portal which is known as the most alumni websites that is having various operations. Overall, the system is very user-friendly and it consists of more than five taps so user can do many tasks via this portal [20]. Nizwa University provides an alumni portal as a part in its main website. Nizwa alumni portal is a simple website with a limited function [15]. Caledonian College is very keen on its students in which it works to keep them in contact with their college. So they provided an effective alumni portal in its main website to keep alumni communicate and see current status of Caledonian College [5]. Majan Alumni portal is also part of the college main website, users are only do registration through a google form [16]. A cross platform mobile application developed to keep alumni utilizing all alumni association services [8]. The need of alumni portal is clearly discussed in this research. The researchers (2017) explains the terms of sharing knowledge among the portal users and how the interaction between alumni themselves can be increased if the colleges and universities are having alumni portal[11]. Sabrina and Daniel (2014) demonstrates some examples of data mining mechanism that helps doing data testing. An experts are needed to perform a good data testing and data analysis to ensure a good data quality, and these can be considered as the organizations approaches. Using Knowledge of data discovery (KDD) can helps in ensuring having the validate data which helps to increase the quality after a good analysis and DSS [21]. The researcher point out the steps of discovering the knowledge and discussed how the knowledge can be discovered by going through three separated processes.

\section{RESULTS AND DISCUSSION}




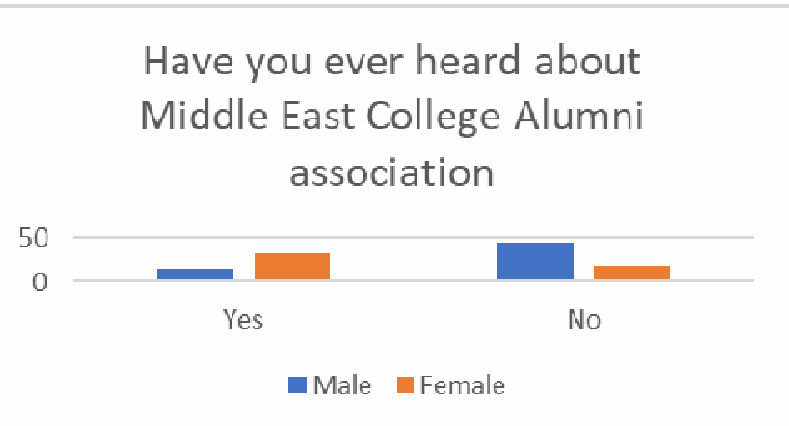

Fig 3 chart of association popularity

The above line chart present how students aware about the college's alumni association. The numbers are very variable between females and males. The blue bar illustrates the number of males who answered this question. It can be seen that the number of males who haven't hear about Middle East College alumni association is greater than the females' number who answered no. Around 32 from 50 females heard about this association.

\section{Do you like to be aware of what is happening at your university...}

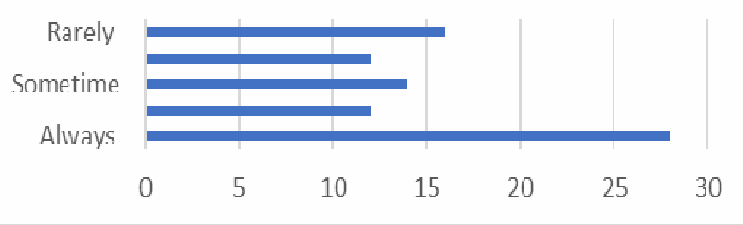

Fig 4 chart of student's awareness.

This blue bar shows the number of students who like to know what is going on in their college. Most students are very interested to know the college events in which around 40 students answered always and usually they like to know what is happening in their college. Around 12 students said that they never being interested to know about college events. Overall, it can be seen that there is a zigzagged bars show how different opinions are in this respect.

\section{Do you prefer to have a mobile application for MEC alumni association}

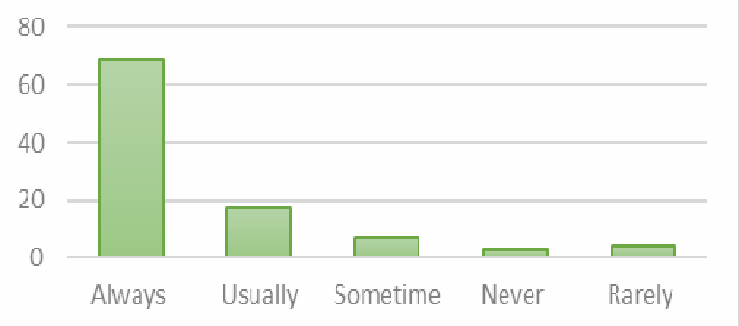

Fig 4 chart of student preference for having mobile application for Middle East College.
The above bar chart presents the extent to which students need a mobile application that brings MEC graduates together. There is a dramatical increase on the number of students who were preferring to have a mobile application for Middle East College in which from 100 student from Middle East College around 69 student who always preferring to have a mobile application for the alumni.

\section{CONCLUSION}

Alumni mobile application can be very important for each institution as it brings the institution's alumni and the existing students in one platform, it will increase the interaction between the alumni and their colleges and Universities, and make the alumni close to the current students. The proposed mobile application is an android mobile application developed using android studio and firebase as the database. This application provides an interactive platform where different type of users can communicate and interact with each other. In the mobile application simple data mining algorithms are performed for more interactive between the alumni and current students.

In future we plan to have a cross platform mobile application running on different mobile platforms such as Android and iOS to let iOS users to have the ability to use the app. So any alumni can use the app and get the opportunity to be a mentor and do mentoring to other alumni or any MEC students and guide them and advice in them in any sector that he/she have an experience on.

\section{REFERENCES}

[1] Alegado, L. (2015). Online Alumni Information System Satisfies Alumni in an Educational Institution in Cebu City, Philippines. JPAIR Institutional Research, 6(1).

[2] applying data mining techniques on acadamic institutional system using WEKA. (2018). International Journal of Recent Trends in Engineering and Research, pp.86-88.

[3] Arote, J., Chintamani, Y.B, ... Pujari, V.D, 2016. Online Alumni System 4, 59-62.

[4] Biesanz, G., Goode, M., Savin, L., 2014. Building Business Relationships through Strategic Alumni Development.

[5] Cce.edu.om. (2018). Caledonian College of Engineering. [online] Available at: http://www.cce.edu.om/contentdetails.aspx?id=298 [Accessed 11 Dec. 2018].

[6] Chi, H., Jones, E. and Grandham, L. (2012). Enhancing Mentoring Between Alumni and Students via Smart Alumni System. Procedia Computer Science, 9, pp.1390- 1399.

[7] Dolbert, S.C., 2002. Future Trends in Alumni Relations. 16th Australian International Education Conference 1- 14.

[8] Egan, D., Cockill, J., 2012. Enhancing Student learning and development in cooperation with our alumni. Student Engagement and Experience Journal 1, 1-12. doi:10.7190/seej.v1i1.36

[9] Guan, Y. and Zhang, W. (2016). Data Mining Based on the Rough Analysis and the Application in the Telecommunication Network Quality Evaluation. TELKOMNIKA (Telecommunication Computing Electronics and Control), 14(3A), p.313.

[10] India, A. (2018). Australian Alumni Association India. [online] Australian Alumni Association India. Available at: https://www.australianalumni.in/ [Accessed 11 Dec. 2018].

[11] Kumar, A. (2014) 'A Framework for Developing an Alumni 
Interactive System of Private Higher Educational Institutions Using Data Mining Techniques’, 8491, pp. 1-7.

[12] Menezes, T. P. et al. (2013) 'Students' and Alumni's profiles analysis through the data mining technique: A case study in the Federal Institute in Rio de Janeiro State interior', (May2014). Available https://www.scopus.com/inward/record.uri?eid=2-s2.084929377324\&partnerID=40\&md5=b992795195a53ff96cf41 b15fc58c915.

[13] Moeller, E. (2014). Purdue University Dance Marathon: Creating Value for PUDM and the Student Community. Purdue Journal of Service-Learning and International Engagement, 1(1), pp.30-31.

[14] Unizwa.edu.om. (2019). [online] Availableat: http://www.unizwa.edu.om/index.php?contentid=1229 [Accessed 23 Apr. 2019].

[15] User, S. (2019). Alumni - Majan University College. [online]
Majancollege.edu.om. Available https://www majancollege edu.om/the-alumni Accessed at: Apr. 2019].

[16] Patil, C., Patil, N., ... Chavan, S., 2017. Alumni Interactive System Using Mining 7, 15335-15336.

[17] Priest, K. and Donley, S. (2014). Developing Leadership for Life: Outcomes from a Collegiate Student-Alumni Mentoring Program. Journal of Leadership Education, 13(3), pp.107-117.

[18] Soharuni.edu.om. (2018). [online] Available at: https://www.soharuni.edu.om/sualumni/ [Accessed 11 Dec. 2018].

[19] Soler, S. V. and Yankelevich, D. (2014) 'Quality Mining A Data Mining Based Method for Data Quality Evaluation’, Pattern Recognition, (May), pp. 162-172.

[20] Squ.edu.om. (2019). Sultan Qaboos University. [online] Available at: https://www.squ.edu.om/Default.aspx [Accessed 23 Apr. 2019]. 